\title{
Aplikasi Pengenalan Penyakit Kejiwaan Manusia Menggunakan Metode Certainty Factor Berbasis Android
}

\author{
Kristono* $^{* 1}$, Ony Budi Prasetyo ${ }^{2}$, Sri Irjani Sholihah ${ }^{3}$ \\ ${ }^{1,3}$ Program Studi Sistem Informasi, STMIK AUB, Surakarta, Indonesia \\ ${ }^{2}$ Program Studi Teknik Komputer, STMIK AUB, Surakarta, Indonesia \\ e-mail: *11kristono@stmik-aub.ac.id, ${ }^{2}$ ony.prast@gmail,com, ${ }^{3}$ irjanisholihah@gmail.com
}

\begin{abstract}
Abstrak
Pada penelitian ini bertujuan membuat Sistem Pakar Kejiwaan Berbasis Android dengan menerapan metode certainty factor dengan menggunakan bahasa pemrograman PHP, database MySQL dan metode pendekatan Waterfall. Metode pengumpulan data yaitu menggunakan metode wawancara, metode observasi dan metode pustaka. Metode analisis kelemahan sistem menggunakan PIECES. Sistem ini dibuat agar seseorang dapat mengetahui dan menanggulangi penyakit yang dideritanya. Sistem pakar untuk diagnosa penyakit kejiwaan ini merupakan suatu sistem pakar yang dirancang sebagai alat bantu untuk mendiagnosa penyakit kejiwaan dengan basis pengetahuan yang dinamis. Dimana sistem pakar merupakan sistem komputer yang berisi penalaran seorang pakar yang memiliki keahlian tertentu dan sistem pakar juga dapat sebagai pengganti peran seorang pakar yang prinsip kerjanya dapat memberikan hasil yang pasti, menggunankan metode certainty factor. Sistem pakar ini akan menampilkan pertanyaan gejala yang dapat dipilih oleh user, dimana setiap pilihan gejala user terdapat nilai dan nilai tersebut diakumulasi dengan nilai gejala oleh pakar. Pada hasil akhir, sistem akan menampilkan hasil diagnosa user, dan penyakit yang diderita. Sistem tersebut memberikan hasil berupa kemungkinan penyakit yang dialami beserta persentase keyakinan, dan user dapat berkonsultasi dengan pakar.
\end{abstract}

Kata kunci-Sistem Pakar, Gangguan Kejiwaan, Certainty Factor, Andorid

\begin{abstract}
In this study the authors established the android - based psychological system by applying fungfactor methods by using PHP programming language, mysql database and waterfall approach methods. The data-gathering method is using interview methods, observation methods and library methods. The system's weak analysis using pieces. It was designed so that one could know and cope with the disease. The system of experts for the diagnosis of psychiatric disorders is an ingenious system designed as an aid to diagnosing psychological illnesses with a dynamic basis for knowledge. Where an expert system is a computer system containing reasoning from an expert with a specific skill and an expert system can also replace the role of an expert whose work principles can give a definite result, utilizing the methods of influence. The system of experts will feature questions of symptoms that the user can choose, in which each user's symptom is associated with that value and value by the expert. At the end, the system will run a diagnostic on the user, and a disease of the user. The system results ina possible disease along with a percentage of confidence, and the user may consult experts.
\end{abstract}

Keywords — Expert System, Psychiatric Disorders, Certainty Factor, Andorid 


\section{PENDAHULUAN}

Gangguan jiwa adalah gangguan alam : cara berpikir (cognitive), kemauan (volition), emosi (affective), tindakan (psychomotor). Gangguan jiwa merupakan kumpulan dari keadaankeadaan yang tidak normal, baik yang berhubungan dengan fisik, maupun dengan mental. Keabnormalan tersebut dibagi ke dalam dua golongan yaitu : gangguan jiwa (Neurosa) dan sakit jiwa (Psikosa). Keabnormalan terlihat dalam berbagai macam gejala yang terpenting diantaranya adalah ketegangan, rasa putus asa dan murung, gelisah, cemas, perbuatan-perbuatan yang terpaksa, histeria, rasa lemah, tidak mampu mencapai tujuan, takut, pikiran-pikiran buruk $[1,5]$.

Macam-macam gangguan kejiwaan antara lain adalah gangguan Skizofernia, gangguan Waham, gangguan Skizotipal, gangguan Suasana Perasaan, gangguan disosiatif, dan lain sebagainya. Gangguan disosiatif merupakan gangguan adanya kehilangan dari integrasi normal. Seseorang yang memiliki gangguan kejiwaan harus melakukan konsultasi pengobatan dan mencari pakar yang ahli dalam bidang kejiwaan. Biasanya untuk mengetahui ada dan tidaknya gejala gangguan kejiwaan pada seseorang harus melakukan konsultasi kepada dokter ahli gangguan kejiwaan. Dengan cara mendatangi langsung dokter tersebut dan pastinya membutuhkan biaya yang tidak sedikit dalam setiap konsultasinya.

Dengan memanfaatkan teknologi informasi dan pengetahuan dari seorang ahli gangguan kejiwaan dapat membantu memberikan pembelajaran kepada masyarakat untuk mengetahui tentang gejala-gejala penyakit kejiwaan sejak dini dengan cara membangun aplikasi pengenalan penyakit kejiwaan. Untuk dapat membangun aplikasi diperlukan analisis dan perancangan data yang akan digunakan, maka dilakukanlah penelitian dengan tujuan untuk melakukan analisa dan perancangan aplikasi menggunakan metode Certainty Factor. Faktor kepastian (Certainty Factor) menyatakan dalam sebuah kejadian (fakta atau hipotesis) berdasarkan bukti atau penilaian pakar. Certainty Factor menggunakan suatu nilai untuk menghitung derajat keyakinan seorang pakar terhadap suatu data.

Berdasarkan latar belakang masalah, maka penelitian ini bertujuan merancang dan membuat aplikasi pengenalan penyakit kejiwaan manusia menggunakan metode certainty factor berbasis android. Penelitian ini menggunakan metode certainty factor karena dapat menggambarkan tingkat keyakinan pakar. Aplikasi ini dapat sebagai media pengenalan penyakit kejiwaan yang di dalamnya berisi informasi tentang beberapa jenis penyakit kejiwaan dan dapat mendiagnosa penyakit dari beberapa gejala yang muncul dan dapat digunakan untuk konsultasi dengan pakar.

\section{METODE PENELITIAN}

\subsection{Metode Pengembangan Sistem}

Dalam pembuatan peneliti menggunakan metode pengembangan sistem dengan metode Waterfall. Metode ini dipilih oleh peneliti karena mempunyai tahapan sistem yang terstruktur sehingga sesuai dalam ruang lingkup penelitian dan pengembangan sistem dengan metode Waterfall. Metode Waterfall adalah suatu proses pengembangan perangkat lunak berurutan, di mana model ini melakukan pendekatan secara sistematis dan urut mulai dari level kebutuhan sistem lalu menuju ke tahap analisis, desain, coding, testing/ verification, dan maintenance. Disebut dengan Waterfall karena tahap demi tahap yang dilalui harus menunggu selesainya tahap sebelumnya dan berjalan berurutan. Metode Waterfall dapat dilihat pada Gambar 1 berikut. 


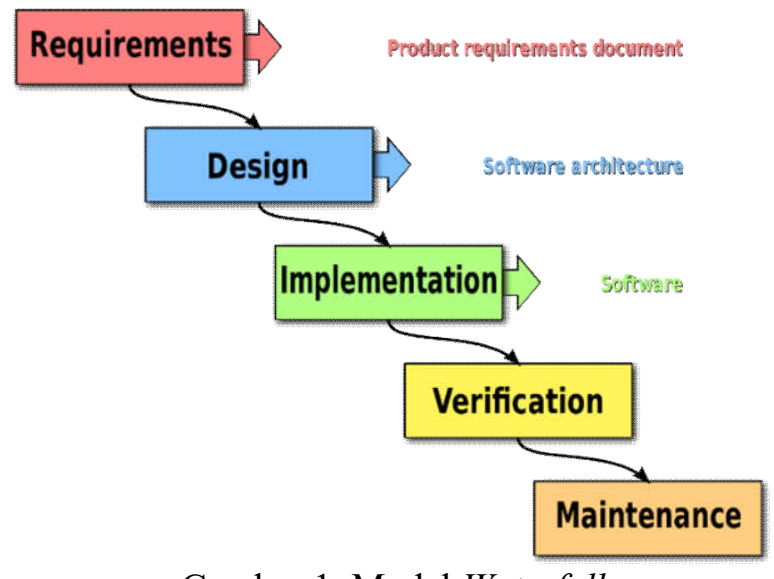

Gambar 1. Model Waterfall

\subsection{Flowchart}

Aplikasi Sistem Pakar Penyakit Kejiwaan dibuatkan gambaran flowchart seperti Gambar 2, agar pengguna dapat mengerti alur program yang dibangun.

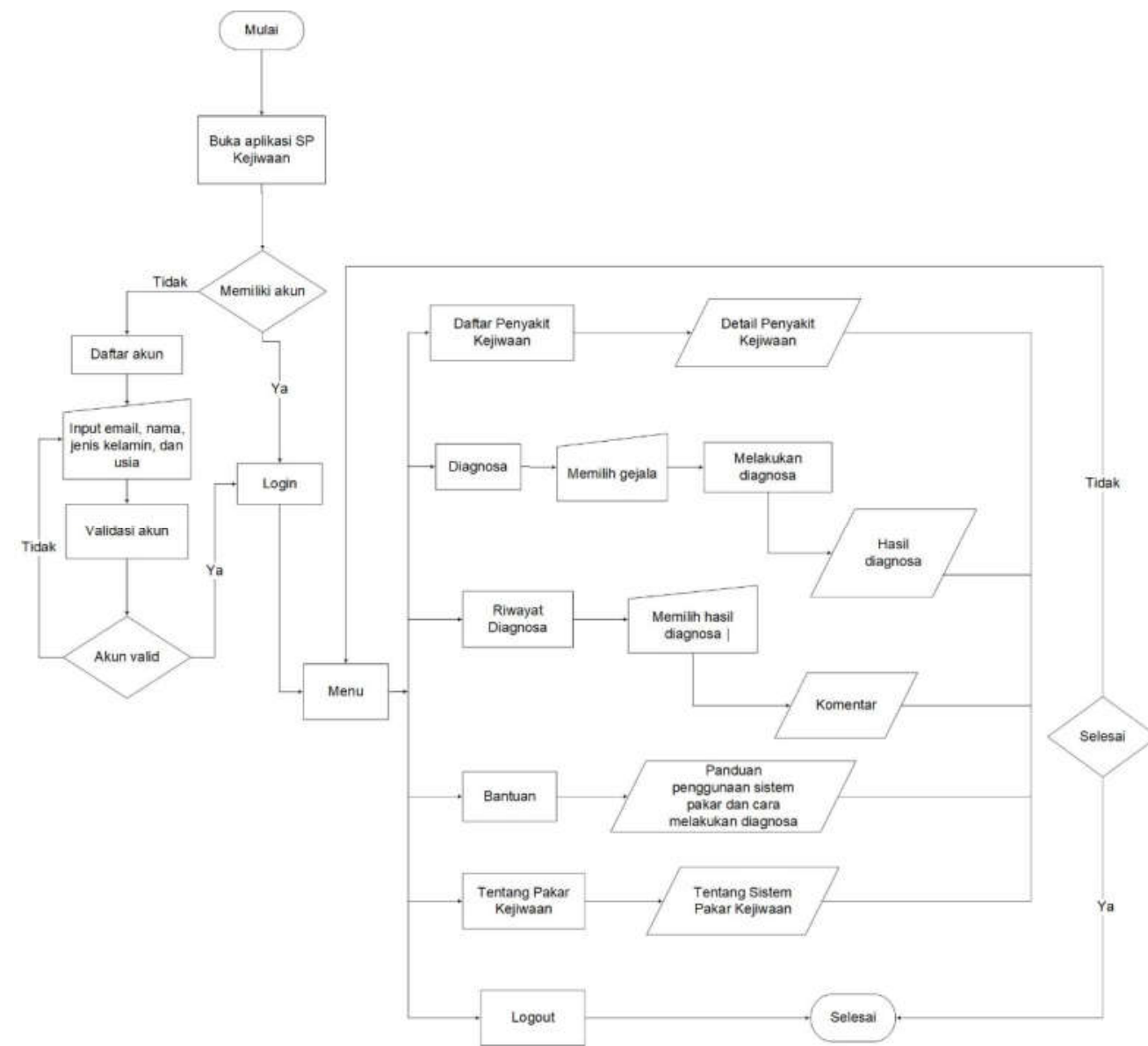

Gambar 2. Flowchart Sistem Pakar Penyakit Kejiwaan

Pada Gambar 2 merupakan flowchart aplikasi sistem pakar penyakit kejiwaan. Sistem ini bermula dari pengguna membuka aplikasi, jika belum memiliki akun pilih daftar akun, lalu masukkan email, password, nama, jenis kelamin, dan usia. Jika akun belum valid silahkan kembali masukkan email, password, nama, jenis kelamin, dan usia. Jika akun valid, dapat melakukan login. Setelah melakukan login pengguna dapat memilih menu. Pilih menu daftar 
penyakit kejiwaan, tampil detail informasi penyakit kejiwaan. Pilih menu diagnosa, silahkan pilih gejala, kemudian sistem melakukan diagnosa dan tampil hasil diagnosa. Pilih menu riwayat diagnosa, dapat memilih hasil diagnosa, tampil komentar. Pilih menu bantuan, tampil panduan penggunaan aplikasi dan cara melakukan diagnosa. Pilih menu tentang pakar kejiwaan, tampil informasi tentang sistem pakar kejiwaan. Pilih logout, maka keluar dari tampilan menu atau selesai.

\subsection{Usecase}

Usecase mendiskripsikan sebuah interaksi antara lebih aktor dengan sistem informasi yang akan dibuat. Aplikasi Sistem Pakar Penyakit Kejiwaan Manusia Menggunakan Metode Certainty Factor akan dibahas dalam usecase yaitu mengenai interaksi antar aktor yang meliputi pengguna aplikasi dan admin seperti pada Gambar 3 berikut.

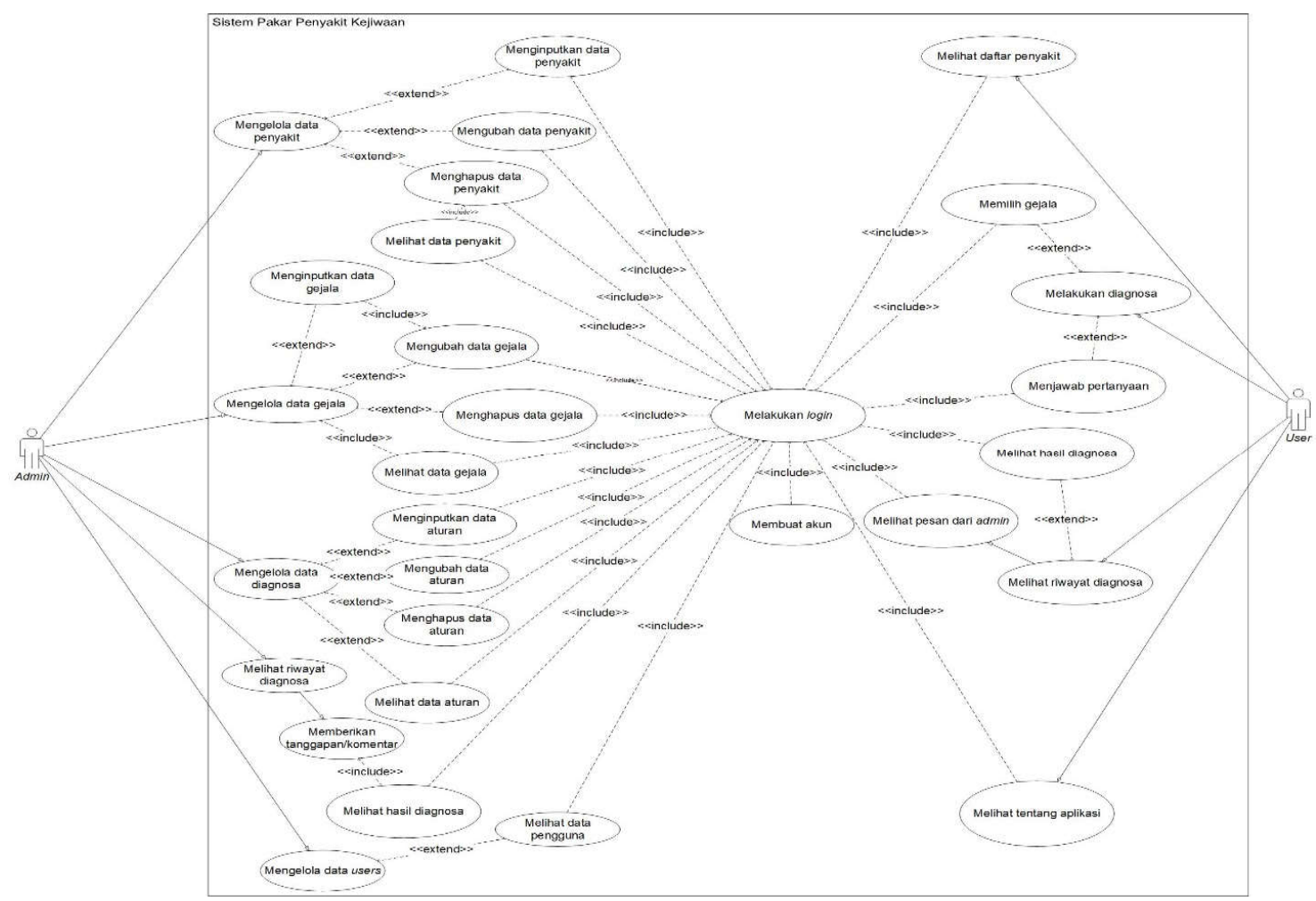

Gambar 3. Usecase

Usecase pada Gambar 3 menunjukkan bahwa admin dapat mengelola data penyakit, admin dapat mengelola data gejala, admin dapat mengelola data diagnosa, admin dapat melihat riwayat diagnosa, memberikan tanggapan/konsultasi, dan dapat mengelola data users. User dapat melihat daftar penyakit, melakukan diagnosa, melihat riwayat diagnosa, dan user dapat melakukan konsultasi dengan admin. Untuk melakukan semua itu admin dan user harus login terlebih dahulu.

\subsection{Activity Diagram}

Activity diagram Aplikasi Sistem Pakar Penyakit Kejiwaan Menggunakan Metode Certainty Factor menggambarkan alur aktivitas dalam sistem yang sedang dirancang. Dimulai dari user membuka aplikasi, kemudian melakukan login. Sistem menampilkan daftar menu, user memilih menu daftar penyakit. Admin menginputkan data penyakit, sistem menampilkan detail informasi penyakit kejiwaan. User memilih menu diagnosa, Admin menginputkan data gejala, sistem menampilkan halaman diagnosa yang berisikan pilihan gejala. User memilih gejala, lalu sistem melakukan diagnosa. Admin menginputkan data rule atau aturan diagnosa penyakit, 
sistem menampilkan hasil diagnosa. User memilih menu riwayat diagnosa, sistem menampilkan daftar hasil diagnosa. Admin melihat daftar pengguna, kemudian memberikan komentar/tanggapan. User memilih daftar hasil diagnosa, sistem menampilkan komentar. User memilih menu bantuan, sistem menampilkan panduan penggunaan aplikasi sistem pakar kejiwaan dan cara melakukan diagnosa. User memilih menu tentang, sistem menampilkan informasi tentang pakar kejiwaan. User memilih logout, dan selesai. Berikut Gambar 4 activity diagram aplikasi.

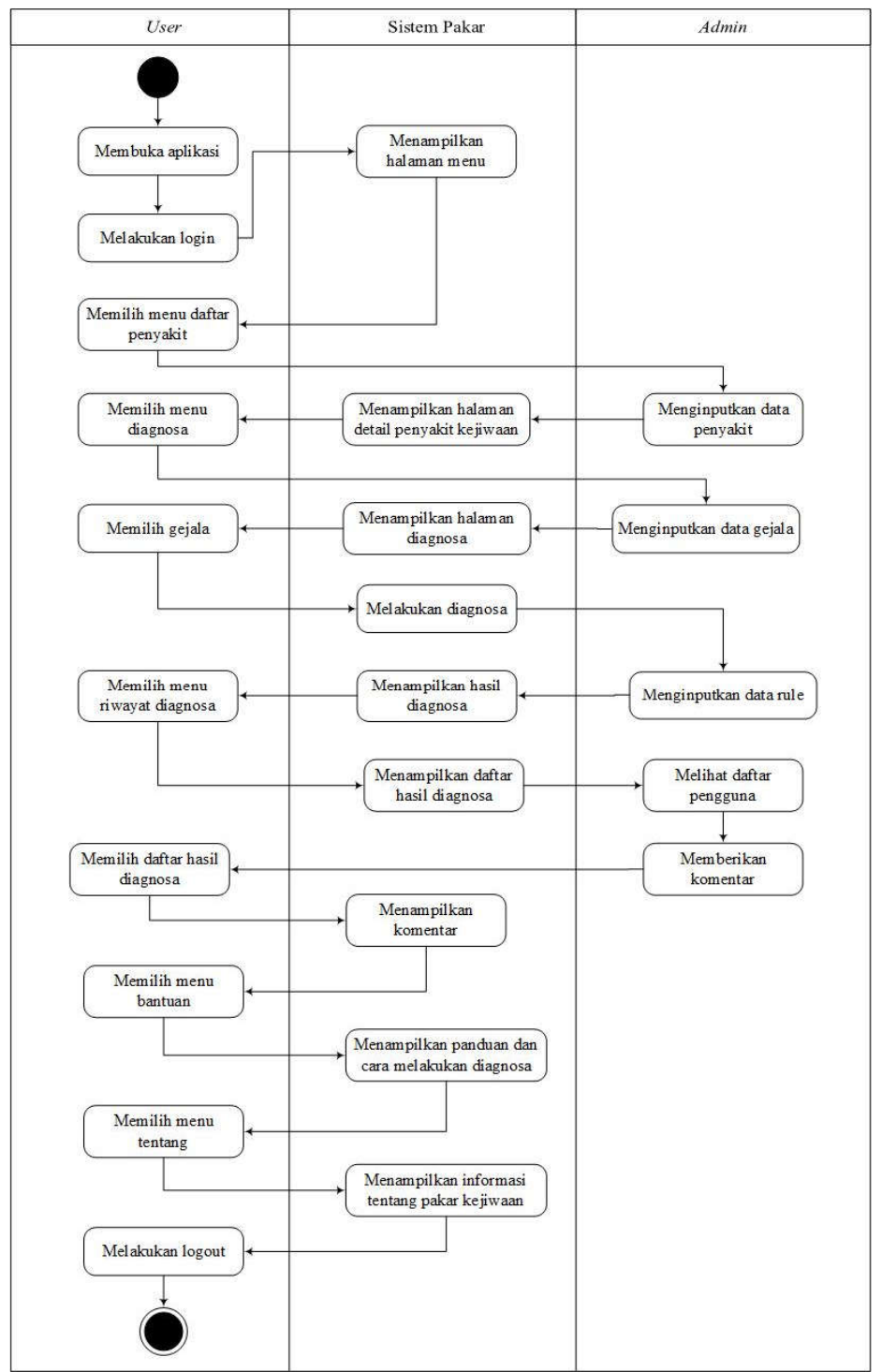

Gambar 4. Activity Diagram

\subsection{Class Diagram}

Diagram kelas (class diagram) adalah sebuah spesifikasi yang diinstansiasi akan menghasilkan sebuah objek dan merupakan inti dari pengembangan dan desain berorientasi objek. Berikut Gambar 5 class diagram aplikasi. 


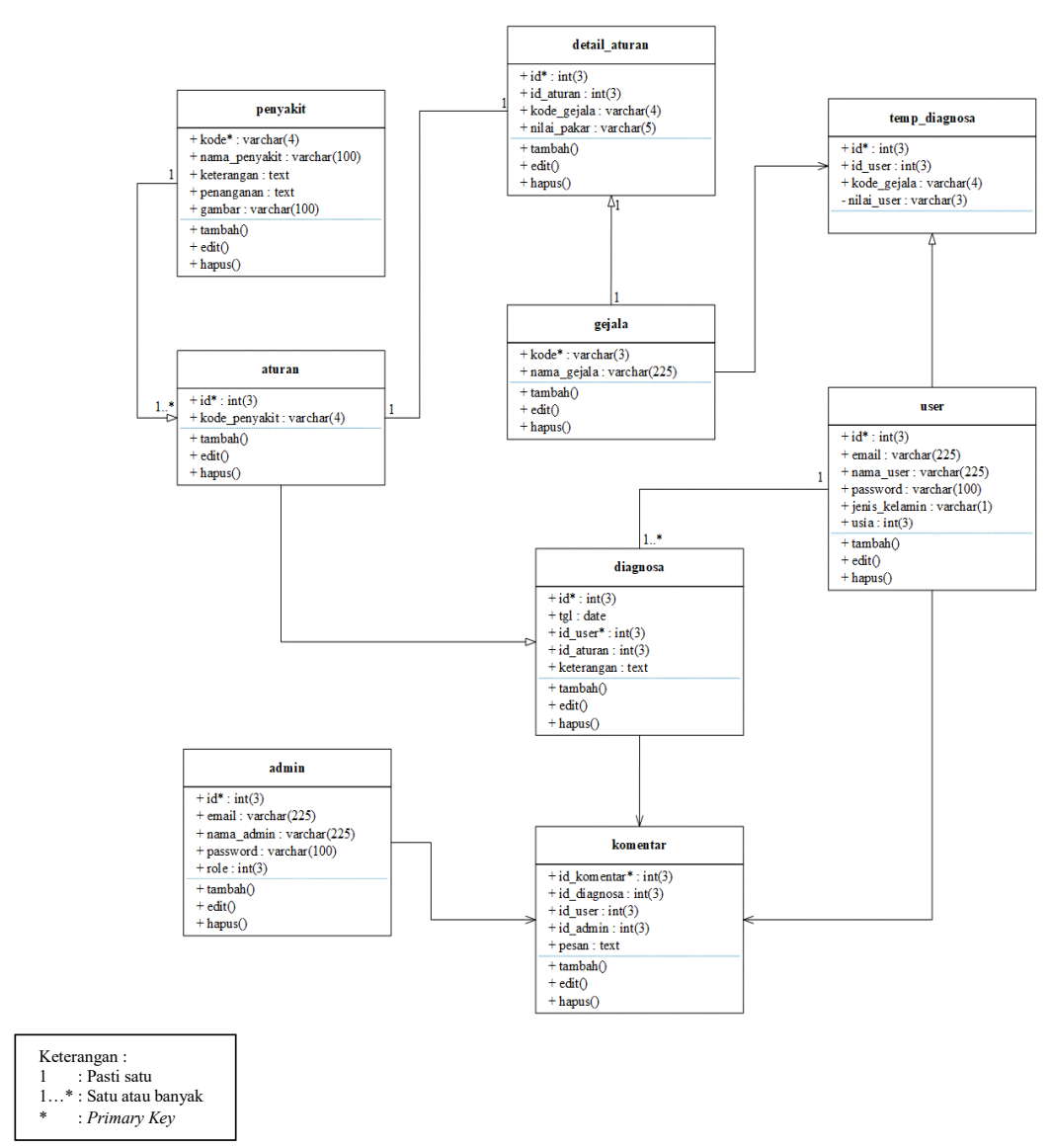

Gambar 5. Class Diagram

Keterangan Gambar 5, pada tabel aturan mengambil kode_penyakit dari tabel penyakit dan setiap aturan pasti memiliki detail aturan. Pada tabel detail_aturan mengambil kode_gejala dari tabel gejala, dan kode_gejala dari tabel gejala dan id_user dari tabel user digunakan pada tabel temp_diagnosa. Pada tabel diagnosa mengambil id_aturan dari tabel aturan dan setiap tabel diagnosa pasti memiliki id_user. Pada tabel komentar mengambil id_diagnosa dari tabel diagnosa, mengambil id_admin dari tabel admin, dan mengambil id_user dari tabel user.

\subsection{Metode Certainty Factor}

Certainty Factor (CF) adalah untuk mengakomodasi ketidakpastian pemikiran seorang pakar yang di usulkan oleh Shortliffe dan Buchanan pada tahun 1975. Seorang pakar (misalnya dokter) sering menganalisis informasi yang ada dengan ungkapan ketidakpastian, untuk mengakomodasi hal ini menggunakan Certainty Faktor guna menggambarkan tingkat keyakinan pakar terhadap masalah yang sedang dihadapi. Faktor kepastian (Certainty Factor) menyatakan kepercayaan dalam sebuah kejadian (fakta atau hipotesa) berdasar bukti atau penilaian pakar [4].

Certainty Factor menggunakan suatu nilai untuk mengasumsikan derajat keyakinan seorang pakar terhadap suatu data. Dalam mengekspresikan derajat kepastian, Certainty Factor untuk mengasumsikan derajat kepastian seorang pakar terhadap suatu data dapat menggunakan formulasi yang diperkenalkan oleh Shortliffe Buchanan dalam pembuatan MYCIN [4]. Konsep formulasi rumusan dasar sebagai berikut :

$$
\mathrm{CF}[\mathrm{H}, \mathrm{E}]=\mathrm{MB}[\mathrm{H}, \mathrm{E}]-\mathrm{MD}[\mathrm{H}, \mathrm{E}]
$$


Keterangan :

$\mathrm{CF}=$ Certainty Factor dalam hipotesa $\mathrm{H}$ yang dipengaruhi oleh fakta $\mathrm{E}$

$\mathrm{MB}(\mathrm{H}, \mathrm{E})=$ measure of belief (ukuran kepercayaan) terhadap hipotesa $\mathrm{H}$, jika diberikan evidence $\mathrm{E}$ (antara 0 dan 1)

$\mathrm{MD}(\mathrm{H}, \mathrm{E})=$ measure of disbelief (ukuran kepercayaan) terhadap evidence $\mathrm{H}$, jika diberikan evidence $\mathrm{E}$ (antara 0 dan 1$)$

$\mathrm{H} \quad=$ Hipotesa

$\mathrm{E} \quad=$ Evidence (peristiwa atau fakta)

Dimana :

$$
\mathrm{CF}[\mathrm{H}, \mathrm{E}] 1=\mathrm{CF}[\mathrm{H}] * \mathrm{CF}[\mathrm{E}]
$$

$\mathrm{CF}(\mathrm{E})=$ Certainty Factor evidence $\mathrm{E}$ yang dipengaruhi oleh evidence $\mathrm{E}$

$\mathrm{CF}(\mathrm{H})=$ Certainty Factor hipotesa dengan asumsi evidence diketahui dengan pasti

$\mathrm{CF}(\mathrm{H}, \mathrm{E})=$ Certainty Factor hipotesa yang dipengaruhi oleh evidence e diketahui dengan pasti

Certainty Factor untuk kaidah dengan kesimpulan yang serupa (similarly concluded Rules) :

CFcombine $\mathrm{CF}[\mathrm{H}, \mathrm{E}] 1,2=\mathrm{CF}[\mathrm{H}, \mathrm{E}] 1+\mathrm{CF}[\mathrm{H}, \mathrm{E}] 2 *[1-\mathrm{CF}[\mathrm{H}, \mathrm{E}] 1]$

$$
\text { CFcombine CF[H,E]old,3 = CF[H,E]old + CF[H,E]3 * (1-CF[H,E]old) }
$$

Certainty Factor untuk hasil akhir persentase :

$$
\text { Persentase keyakinan }=\mathrm{CFcombine} * 100
$$

Pada sesi diagnosa penyakit, User diberikan pilihan interpretasi yang dapat dipilih pada saat User memilih pertanyaan gejala dan masing-masing memiliki nilai $\mathrm{CF}$ (User) dapat dilihat pada Tabel 1 sebagai berikut.

Tabel 1 Nilai User untuk empat pilihahan jawaban

\begin{tabular}{|l|l|c|}
\hline No & \multicolumn{1}{|c|}{ Keterangan } & Nilai User \\
\hline 1 & Tidak & 0 \\
\hline 2 & Mungkin & 0,4 \\
\hline 3 & Kemungkinan Besar & 0,6 \\
\hline 4 & Hampir Pasti & 0,8 \\
\hline
\end{tabular}

Nilai Certainty Factor untuk berbagai macam istilah ketidakpastian. Dengan menggali dari hasil wawancara dengan pakar, nilai CF (Rule) didapat dari interpretasi dari pakar menjadi nilai CF tertentu dapat dilihat pada Tabel 2 berikut.

Tabel 2 Nilai Kepastian dari Interpretasi Pakar CF (Rule)

\begin{tabular}{|c|l|c|}
\hline No & \multicolumn{1}{|c|}{ Keterangan } & Nilai Pakar \\
\hline 1 & Pasti Tidak & -1 \\
\hline 2 & Hampir pasti Tidak & $-0,8$ \\
\hline 3 & Kemungkinan Besar Tidak & $-0,6$ \\
\hline 4 & Kemungkinan Tidak & $-0,4$ \\
\hline 5 & Tidak Tahu & $-0,2-0,2$ \\
\hline 6 & Kemungkinan & 0,4 \\
\hline 7 & Kemungkinan Besar & 0,6 \\
\hline 8 & Hampir Pasti & 0,8 \\
\hline 9 & Pasti & 1 \\
\hline
\end{tabular}

Sumber : Khawarizmi [5]

Nilai 0 menentukan bahwa pengguna menginformasikan bahwa user tidak mengalami gejala seperti yang ditanyakan oleh sistem. Semakin pengguna konsultasi yakin bahwa gejala tersebut memang dialami manusia, maka semakin tinggi pula hasil presentase keyakinan yang diperoleh. Proses penghitungan presentase keyakinan diawali dengan pemecahan sebuah kaidah 
yang memiliki premis majemuk, menjadi kaidah-kaidah yang memiliki premis tunggal. Kemudian masing-masing aturan baru dihitung dengan Certainty Factornya, sehingga diperoleh nilai Certainty Factor untuk masing-masing aturan, kemudian nilai Certainty Factor tersebut dikombinasikan.

Metode Certainty Factor ini hanya bisa mengolah dua bobot dalam sekali perhitungan. Untuk bobot yang lebih dari dua banyaknya, untuk melakukan perhitungan tidak terjadi masalah apabila bobot yang dihitung teracak, artinya tidak ada aturan untuk mengkombinasikan bobotnya, karena untuk kombinasi seperti apapun hasilnya akan tetap sama. Untuk mengetahui apakah seorang pasien tersebut menderita penyakit kejiwaan atau tidak, itu dilihat dari hasil perhitungan bobot setelah semua keluhan-keluhan diinputkan dan semua bobot dihitung dengan menggunakan metode Certainty Factor. Pasien yang divonis mengidap penyakit kejiwaan adalah pasien yang memiliki hasil persentase dari Certainty Factor yang lebih tinggi.

\subsection{Basis Pengetahuan}

Dalam mempresentasikan pengetahuan yang berupa fakta-fakta gejala, jenis gangguan kejiwaan serta solusi menggunakan kaidah produksi. Kaidah produksi merupakan salah satu aturan bentuk representasi pengetahuan yang banyak digunakan dalam pengembangan sistem pakar. Representasi pengetahuan dengan kaidah produksi, pada dasarnya berupa aturan (rule) yang berupa IF-THEN. Berikut ini adalah reprentasi pengetahuan untuk aplikasi pengenalan penyakit kejiwaan menggunakan metode certainty factor dengan kaidah produksi di bawah ini : Untuk kaidah produksi atau rule yang berkaitan dengan penyakit kejiwaan Skizofernia adalah :

IF berbicara sendiri

$A N D$ berbicara kacau (bicara dengan cepat dan iramanya tidak menentu)

$A N D$ bicaranya tidak nyambung

$A N D$ tertawa sendiri

$A N D$ berhalusinasi (kondisi seseorang dapat melihat, mencium, mendengar atau merasakan sesuatu yang tidak nyata)

$A N D$ memiliki pemikiran yang salah tetapi diyakini benar dan tidak dapat dibantah oleh oranglain

THEN skizofernia

Untuk kaidah produksi atau rule yang berkaitan dengan penyakit kejiwaan Depresi Ringan adalah :

IF memiliki perasaan cemas/sedih berlebihan

$A N D$ kehilangan minat dan kegembiraan

$A N D$ tidur terganggu

AND nafsu makan berkurang

THEN depresi ringan

Untuk kaidah produksi atau rule yang berkaitan dengan penyakit kejiwaan Depresi Sedang adalah :

IF memiliki perasaan cemas/sedih berlebihan

$A N D$ kehilangan minat dan kegembiraan

$A N D$ tidur terganggu

$A N D$ konsentrasi dan perhatian berkurang

$A N D$ memiliki pemikiran tentang rasa bersalah dan tidak berguna

THEN depresi sedang

Untuk kaidah produksi atau rule yang berkaitan dengan penyakit kejiwaan Depresi Berat adalah:

IF memiliki perasaan cemas/sedih berlebihan

$A N D$ kehilangan minat dan kegembiraan

$A N D$ mudah merasa lelah walau melakukan pekerjaan ringan

$A N D$ merasa tidak memiiki harga diri dan kurang percaya diri

$A N D$ tidak memiliki padangan masa depan yang bagus dan mudah putus asa

$A N D$ memiliki pemikiran tentang rasa bersalah dan tidak berguna 
$A N D$ memiliki pikiran untuk mambahayakan diri atau bunuh diri

THEN depresi berat

Untuk kaidah produksi atau rule yang berkaitan dengan penyakit kejiwaan Cemas Menyeluruh adalah :

IF merasa cemas atau khawatir tentang nasib buruk dan cepat putus asa

$A N D \quad$ sulit konsentrasi

$A N D$ sakit kepala

$A N D$ gemetaran dan berkeringat

$A N D$ sesak nafas

THEN cemas menyeluruh

Untuk kaidah produksi atau rule yang berkaitan dengan penyakit kejiwaan Anxietas Fobik adalah :

IF mengalami ketakutan yang besar

$A N D$ shock hebat mengenai situasi atau objek tertentu

$A N D$ cepat lelah

$A N D$ panik dan berkeringat

THEN anxietas fobik

Untuk kaidah produksi atau rule yang berkaitan dengan penyakit kejiwaan Afektif/mood adalah:

IF tingkat aktivitasnya terganggu (kadang mood meningkat dan kadang mood menurun)

$A N D$ memiliki pemikiran yang kacau

$A N D$ susah tidur

$A N D$ berkeinginan menjauhkan diri dari masyarakat

THEN afektif/mood

Dari kaidah produksi di atas dapat dibuatkan tabel basis pengetahuan data gejala yang dapat dilihat pada Tabel 3 dan tabel basis pengetahuan data penyakit pada Tabel 4. Basis pengetahuan pada tabel-tabel ini yang diterapkan dalam aplikasi pengenalan penyakit kejiwaan. 
Tabel 3. Gejala Penyakit

\begin{tabular}{|c|c|c|}
\hline No & Kode & Gejala Penyakit \\
\hline 1 & G001 & berbicara sendiri sekurang-kurangnya 1 bulan \\
\hline 2 & G002 & $\begin{array}{l}\text { berbicara kacau (bicara dengan cepat dan iramanya tidak menentu) } \\
\text { sekurang-kurangnya } 1 \text { bulan }\end{array}$ \\
\hline 3 & G003 & bicaranya tidak nyambung sekurang-kurangnya 1 bulan \\
\hline 4 & G004 & tertawa sendiri sekurang-kurangnya 1 bulan \\
\hline 5 & G005 & $\begin{array}{l}\text { berhalusinasi (kondisi seseorang dapat melihat, mencium, mendengar atau } \\
\text { merasakan sesuatu yang tidak nyata) sekurang-kurangnya } 1 \text { bulan }\end{array}$ \\
\hline 6 & G006 & $\begin{array}{l}\text { memiliki pemikiran yang salah tetapi diyakini benar dan tidak dapat } \\
\text { dibantah oleh orang lain sekurang-kurangnya } 1 \text { bulan }\end{array}$ \\
\hline 7 & G010 & nafsu makan berkurang sekurang-kurangnya 2 minggu \\
\hline 8 & G011 & memiliki perasaan cemas/sedih berlebihan sekurang-kurangnya 2 minggu \\
\hline 9 & G013 & tidur terganggu sekurang-kurangnya 2 minggu \\
\hline 10 & G014 & $\begin{array}{l}\text { konsentrasi dan perhatian berkurang berkurang sekurang-kurangnya } 2 \\
\text { minggu }\end{array}$ \\
\hline 11 & G016 & memiliki perasaan cemas/sedih berlebihan sekurang-kurangnya 2 minggu \\
\hline 12 & G017 & kehilangan minat dan kegembiraan sekurang-kurangnya 2 minggu \\
\hline 13 & G018 & $\begin{array}{l}\text { mudah merasa lelah walau melakukan pekerjaan ringan sekurang- } \\
\text { kurangnya } 2 \text { minggu }\end{array}$ \\
\hline 14 & G019 & $\begin{array}{l}\text { merasa tidak memiiki harga diri dan kurang percaya diri sekurang- } \\
\text { kurangnya } 2 \text { minggu }\end{array}$ \\
\hline 15 & G020 & $\begin{array}{l}\text { tidak memiliki padangan masa depan yang bagus dan mudah putus asa } \\
\text { sekurang-kurangnya } 2 \text { minggu }\end{array}$ \\
\hline 16 & G021 & $\begin{array}{l}\text { memiliki pemikiran tentang rasa bersalah dan tidak berguna sekurang- } \\
\text { kurangnya } 2 \text { minggu }\end{array}$ \\
\hline 17 & G022 & $\begin{array}{l}\text { memiliki pikiran untuk mambahayakan diri atau bunuh diri sekurang- } \\
\text { kurangnya } 2 \text { minggu }\end{array}$ \\
\hline 18 & G023 & $\begin{array}{l}\text { merasa cemas atau khawatir tentang nasib buruk dan cepat putus asa } \\
\text { hampir setiap hari sekurang-kurangnya } 1 \text { minggu }\end{array}$ \\
\hline 19 & G024 & sulit konsentrasi hampir setiap hari sekurang-kurangnya 1 minggu \\
\hline 20 & G025 & sakit kepala hampir setiap hari sekurang-kurangnya 1 minggu \\
\hline 21 & G026 & $\begin{array}{l}\text { gemetaran dan berkeringat hampir setiap hari sekurang-kurangnya } 1 \\
\text { minggu }\end{array}$ \\
\hline 22 & G027 & sesak nafas \\
\hline 23 & G028 & mengalami ketakutan yang besar selama sekurang-kurangnya 1 bulan \\
\hline 24 & G029 & $\begin{array}{l}\text { shock hebat mengenai situasi atau objek tertentu sekurang-kurangnya } 1 \\
\text { bulan }\end{array}$ \\
\hline 25 & G030 & cepat lelah sekurang-kurangnya 1 bulan \\
\hline 26 & G031 & hampir dan berkeringat sekurang-kurangnya 1 bulan \\
\hline 27 & G032 & $\begin{array}{l}\text { tingkat aktivitasnya terganggu (kadang mood meningkat dan kadang mood } \\
\text { menurun) sekurang-kurangnya } 2 \text { minggu }\end{array}$ \\
\hline 28 & G033 & memiliki pemikiran yang kacau sekurang-kurangnya 2 minggu \\
\hline 29 & G034 & susah tidur \\
\hline 30 & G035 & berkeinginan menjauhkan diri dari masyarakat \\
\hline
\end{tabular}

Sumber : Maslim [6] 
Tabel 4. Jenis Penyakit

\begin{tabular}{|l|l|l|}
\hline No & Kode & Jenis Penyakit \\
\hline 1 & P001 & Skizofernia \\
\hline 2 & P002 & Depresi Ringan \\
\hline 3 & P003 & Depresi Sedang \\
\hline
\end{tabular}

\begin{tabular}{|l|l|l|}
\hline No & Kode & \multicolumn{1}{|c|}{ Jenis Penyakit } \\
\hline 4 & P004 & Depresi Berat \\
\hline 5 & P005 & $\begin{array}{l}\text { Gangguan Cemas } \\
\text { Menyeluruh }\end{array}$ \\
\hline 6 & P006 & Gangguan Axientas Fobik \\
\hline
\end{tabular}

\section{HASIL DAN PEMBAHASAN}

\subsection{Hasil antarmuka}

\subsubsection{Halaman Login}

Gambar 6 halaman login user menampilkan email dan password user untuk melakukan login dengan menggunakan akun yang sudah terdaftar pada sistem.

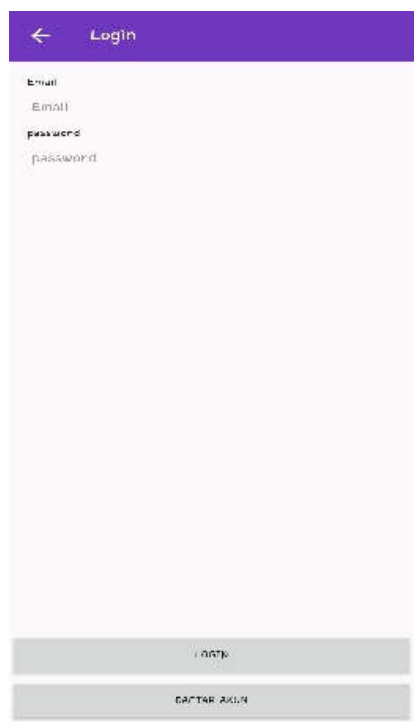

Gambar 6. Halaman login user

\subsubsection{Halaman menu riwayat diagnosa}

Gambar 7 halaman menu riwayat diagnosa menampilkan daftar hasil diagnosa penyakit. Pada halaman ini diberikan fasilitas untuk user dapat memilih hasil diagnosa untuk melihat komentar.

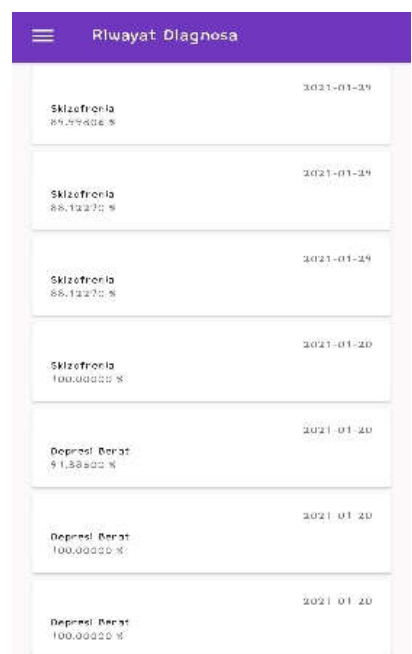

Gambar 10 Halaman menu riwayat diagnose 


\subsubsection{Halaman konsultasi}

Gambar 11 halaman komentar/konsultasi menampilkan pesan antara user dan admin, diberikan fasilitas untuk user dapat menambahkan pesan atau membalas pesan dari admin (user dapat melakukan konsultasi).

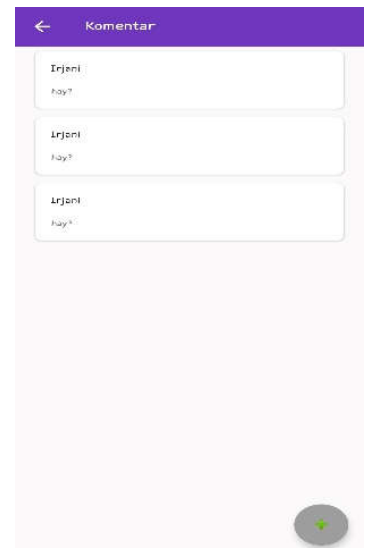

Gambar 11 Halaman komentar/konsultasi

\subsubsection{Halaman menu diagnosa}

Gambar 12 halaman menu gejala menampilkan daftar pertanyaan gejala. Diberikan fasilitas untuk user dapat melakukan diagnosa dengan memilih jawaban dari pertanyaan gejala tersebut.

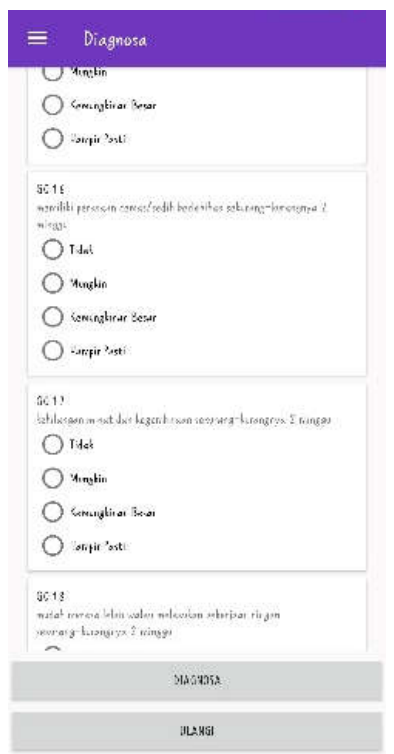

Gambar 12 Halaman menu diagnosa

\subsection{Pembahasan}

Halaman hasil diagnosa akan menampilkan hasil diagnosa penyakit kejiwaan. Dibutuhkan perhitungan yang dapat membantu dalam memberikan diagnosa pada penderita penyakit kejiwaan. Metode perhitungan pada sistem dalam penelitian ini menggunakan metode CF (Certainty Factor). Langkah-langkah penggunaan metode CF dalam proses perhitungan berdasarkan gejala-gejala yang telah diinputkan oleh user dapat dilihat pada contoh kasus berikut ini :

Kasus pertama disini user memilih gejala G001, G002, G003, G004, G005, dan G006. Maka hasil diagnosanya dapat dilihat pada Tabel 5 dan Gambar 13 berikut. 
Tabel 5 Hasil Diagnosa Kasus Pertama

Kode gejala
G001
G002
G003
G004
G005
G006

CFPakar
1
1
0,6
0,4
0,8
0,6

\begin{tabular}{|c|}
\hline CFUser \\
0,6 \\
0,4 \\
0 \\
0 \\
0,8 \\
0 \\
\hline
\end{tabular}

$\mathrm{CF}[\mathrm{H}, \mathrm{E}]$
0,6
0,4
0
0
0,64
0

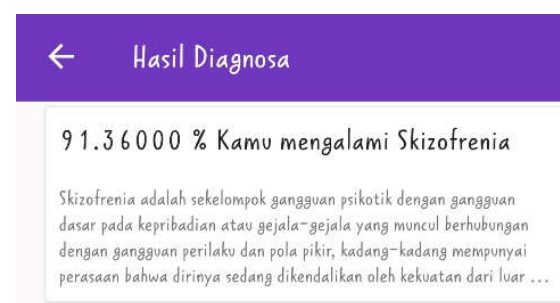

Gambar 13 Hasil diagnosa kasus pertama

Hasil diagnosa pada Gambar 13 melalui proses pehitungan kombinasikan nilai CF dari masingmasing kaidah. Berikut adalah kombinasikan $\mathrm{CF}[\mathrm{H}, \mathrm{E}] 1$ dengan $\mathrm{CF}[\mathrm{H}, \mathrm{E}] 2$ :

$$
\begin{aligned}
\text { CFcombine CF[H,E]1,2 } & =\mathrm{CF}[\mathrm{H}, \mathrm{E}] 1+\mathrm{CF}[\mathrm{H}, \mathrm{E}] 2 *(1-\mathrm{CF}[\mathrm{H}, \mathrm{E}] 1] \\
& =0,6+0,4 *(1-0,6) \\
& =0,6+0,16=0,76 \mathrm{old} \\
\text { CFcombine CF[H,E]old,3 } & =\mathrm{CF}[\mathrm{H}, \mathrm{E}] \mathrm{old}+\mathrm{CF}[\mathrm{H}, \mathrm{E}] 3 *(1-\mathrm{CF}[\mathrm{H}, \mathrm{E}] \mathrm{old}] \\
& =0,76+0 *(1-0,76) \\
& =0,76+0=0,76 \mathrm{old} 2 \\
\text { CFcombine CF[H,E]old2,4 } & =\mathrm{CF}[\mathrm{H}, \mathrm{E}] \mathrm{old} 2+\mathrm{CF}[\mathrm{H}, \mathrm{E}] 4 *(1-\mathrm{CF}[\mathrm{H}, \mathrm{E}] \mathrm{old} 2] \\
& =0,76+0 *(1-0,76) \\
& =0,76+0=0,76 \mathrm{old} 3 \\
\mathrm{CF} \text { combine CF[H,E]old3,5 } & =\mathrm{CF}[\mathrm{H}, \mathrm{E}] \mathrm{old} 3+\mathrm{CF}[\mathrm{H}, \mathrm{E}] 5 *(1-\mathrm{CF}[\mathrm{H}, \mathrm{E}] \mathrm{old} 3] \\
& =0,76+0,64 *(1-0,76) \\
\mathrm{CF} \text { combine CF[H,E]old4,6 } & =0,76+0,1536=0,9136 \mathrm{old} 4 \\
& =0,9136+0 *(1-0,9136) \\
\mathrm{CF}[\mathrm{H}, \mathrm{E}] \mathrm{old} 5 * 100 \% & =0,9136+0=0,9136 \mathrm{old} 5 \\
& =0,9136 * 100 \%=91,36 \%
\end{aligned}
$$

Dengan demikian dapat dikatakan bahwa perhitungan certainty factor pada penyakit kejiwaaan Skizofernia memiliki persentase tingkat keyakinan 91,36\%.

Kasus kedua disini user memilih gejala G028, G029, G030, dan G031. Maka hasil diagnosanya dapat dilihat pada Tabel 6 dan Gambar 14 sebagai berikut.

Tabel 6 Hasil Diagnosa Kasus Kedua

\begin{tabular}{cc|cc} 
Kode gejala & CFPakar & CFUser & CF[H,E] \\
G028 & 0,8 & 0,4 & 0,32 \\
G029 & 0,8 & 0,8 & 0,64 \\
G030 & 0,4 & 0,8 & 0,32 \\
G031 & 0,6 & 0,4 & 0,24
\end{tabular}




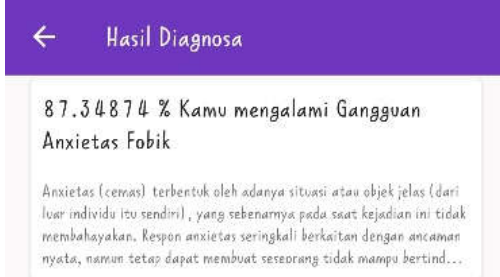

Gambar 14 Hasil diagnosa kasus kedua

Hasil diagnosa pada Gambar 14 melalui proses pehitungan kombinasikan nilai CF dari masingmasing kaidah. Berikut adalah kombinasikan $\mathrm{CF}[\mathrm{H}, \mathrm{E}] 1$ dengan $\mathrm{CF}[\mathrm{H}, \mathrm{E}] 2$ :

$$
\begin{aligned}
& \text { CFcombine } \mathrm{CF}[\mathrm{H}, \mathrm{E}] 1,2=\mathrm{CF}[\mathrm{H}, \mathrm{E}] 1+\mathrm{CF}[\mathrm{H}, \mathrm{E}] 2 *(1-\mathrm{CF}[\mathrm{H}, \mathrm{E}] 1] \\
& =0,32+0,64 *(1-0,32) \\
& =0,32+0,4352=0,7552 \text { old } \\
& \text { CFcombine } \mathrm{CF}[\mathrm{H}, \mathrm{E}] \mathrm{old}, 3=\mathrm{CF}[\mathrm{H}, \mathrm{E}] \mathrm{old}+\mathrm{CF}[\mathrm{H}, \mathrm{E}] 3 *(1-\mathrm{CF}[\mathrm{H}, \mathrm{E}] \mathrm{old}] \\
& =0,7552+0,32 *(1-0,7552) \\
& =0,7552+0,078336=0,833536 \mathrm{old} 2 \\
& \text { CFcombine } \mathrm{CF}[\mathrm{H}, \mathrm{E}] \mathrm{old} 2,4=\mathrm{CF}[\mathrm{H}, \mathrm{E}] \mathrm{old} 2+\mathrm{CF}[\mathrm{H}, \mathrm{E}] 4 *(1-\mathrm{CF}[\mathrm{H}, \mathrm{E}] \mathrm{old} 2] \\
& =0,833536+0,24 *(1-0,833536) \\
& =0,833536+0,03995136=0,87348736 \mathrm{old} 3 \\
& \mathrm{CF}[\mathrm{H}, \mathrm{E}] \mathrm{old} 3 * 100 \%=0,87348736 * 100 \%=87,348736 \%
\end{aligned}
$$

Dengan demikian dapat dikatakan bahwa perhitungan certainty factor pada penyakit kejiwaaan Anxietas Fobik memiliki persentase tingkat keyakinan 87,348736 \%. Dari akumulasi nilai gejala yang dipilih oleh user dengan nilai yang diberikan oleh pakar tersebut dapat disimpulkan bahwa nilai tertinggi dari hasil akhir certainty factor, merupakan hasil diagnosa yang ditampilkan pada sistem pakar penyakit kejiwaan.

\section{KESIMPULAN}

Dari proses penelitian dapat diambil kesimpulan bahwa aplikasi pengenalan penyakit kejiwaan dibangun dan dirancang sebagai media pengenalan penyakit kejiwaan dan dapat digunakan untuk melakukan diagnosa penyakit menggunakan metode certainty factor (kepastian) dari seorang pakar atau dokter spesialis kejiwaan berbasis android yang dapat diakses melalui smartphone, sehingga sangat membantu memberikan pengetahuan mengenai penyakit kejiwaan. Perancangan sistem menggunakan metode waterfall, sedangkan untuk analisis kelemahan sistem menggunakan analisa PIECES serta pemodelan flowchart dan UML (Unified Modeling Language) dengan komponen yang digunakan yaitu usecase diagram, class diagram, activity diagram, sequence diagram, dan desain interface. Sistem dibangun menggunakan bahasa pemrograman javascript, HTML, PHP. Sistem dibangun dengan software Android Studio, android SDK, elementor, database menggunakan MySQL.

\section{SARAN}

Penelitian ini masih dapat dikembangkan lebih lanjut, dengan harapan pada aplikasi yang akan dikembangkan, dilakukan penambahan data gejala penyakit kejiwaan beserta solusi dan cara penangannya, sehingga informasi yang dimiliki oleh sistem semakin banyak. Metode sistem pakar yang digunakan tidak harus menggunakan metode certainty factor, namun dapat dikembangkan dengan membandingkan dengan metode-metode yang lainnya. Pada aplikasi yang akan dikembangkan, menambahkan notifikasi ketika mendapatkan pesan dari admin. 


\section{DAFTAR PUSTAKA}

[1] Mevung, F. I., Suyatno, A., \& Maharani, S. 2017. Diagnosis Penyakit Kejiwaan Menggunakan Metode Certainty Factor. Samarinda: Fakultas Ilmu Komputer dan Teknologi Informasi, Universitas Mulawarman.

[2] Kurniawan, F. Bab II Tinjauan Pustaka. http://repository.ump.ac.id/812/3/FAJAR\%20KURNIAWAN\%20BAB\%20II.pdf. [Accessed: Oktober 2020]

[3] Silvinia, A. M. 2020. Aplikasi Penjualan Alat Musik Gamelan Jawa Berbasis Android Studi Kasus: CV. Resi Larass (Doctoral dissertation, STMIK AUB SURAKARTA).

[4] Daniel, D., \& Virginia, G. 2010. Implementasi sistem pakar untuk mendiagnosis penyakit dengan gejala demam menggunakan metode certainty factor. Jurnal Informatika, 6(1).

[5] Khawarizmi, I. N., Triayudi, A., \& Sholihati, I. D. 2020. Diagnosa Depresi Pada Mahasiswa Menggunakan Metode Certainty Factor dan Forward Chaining. INTI Nusa Mandiri, 14(2), 139-144.

[6] Maslim, Rusdi. 2001. Diagnosa Gangguan Jiwa, Rujukan Ringkas PPDGJ-III. PT Nuh Jaya - Jakarta.

[7] Sari, N. A. 2013. Sistem Pakar Mendiagnosa Penyakit Demam Berdarah Menggunakan Metode Certainty Factor. Pelita Inform. Budi Darma, 4, 100-103. 